ASIMETRIS: JURNAL PENDIDIKAN MATEMATIKA DAN SAINS

$$
\text { p-ISSN } 2721 \text { - 8724, e-ISSN } 2722 \text { - } 0214
$$

Website Jurnal: http://journal.umuslim.ac.id/index.php/asm/

\begin{aligned} & Info Artikel: Direvisi pada 9 Mei 2021 \\ & Disubmit pada 14 April 2021 Diterima pada 11 Mei 2021 \\ & Direview pada 2 Mei 2021 Tersedia secara daring pada 16 Mei 2021 \\ & \hline\end{aligned}

\title{
PERBEDAAN HASIL BELAJAR SISWA YANG DIAJARKAN DENGAN MENGGUNAKAN MODEL PEMBELAJARAN KOOPERATIF TIPE NUMBER HEAD TOGETHER DAN MODEL PEMBELAJARAN KONVENSIONAL
}

\author{
Fralolon Lumamuly ${ }^{1}$, Christina M Laamena ${ }^{2}$, Hanisa Tamalene ${ }^{3}$ \\ 1,2,3Program Studi Pendidikan Matematika, Fakultas Keguruan dan IImu Pendidikan, Universitas Pattimura \\ Alamat email: christinmath18@gmail.com
}

\begin{abstract}
ABSTRAK. Penelitian ini bertujuan untuk mengetahui perbedaan hasil belajar siswa SMP Negeri 2 Taniwel kelas IX pada materi peluang yang menggunakan model pembelajaran konvensional dan model pembelajaran kooperatif tipe number head together. Tipe penelitian yang digunakan adalah penelitian eksperimen (Experimental Research), dengan desain penelitiannya Posttest Only Control Group Design. Populasi dalam penelitian ini adalah siswa kelas IX SMP Negeri 2 Taniwel, Jl. KH. Dewantara, kecamatan Taniwel Timur, kabupaten Seram Bagian Barat yang berjumlah 40 siswa. Sampel dalam penelitian ini adalah siswa kelas $\mathrm{IX}_{1}$ dan siswa kelas $\mathrm{IX}_{2}$. Instrumen yang digunakan dalam penelitian ini adalah instrumen tes akhir. Soal tes hasil belajara yang diberikan terdiri atas 5 soal dalambentuk uraian. Teknik analisis data dalam penelitian ini menggunakan analisis statitistik deskritif dan analisis statistik inferensial (uji-t) atau uji beda rata-rata. Hasil analisis deskritif menunjukan bahwa rata-rata hasil belajar siswa kelas eksperimen sebesar 74,71 dan rata-rata hasil belajar siswa kelas kontrol sebesar 56,91 . Sedangkan hasil uji prasarat menunjukan bahwa data pada kedua sampel berdistribusi normal memiliki varians yang homogen, selanjutnya dilakukan pengujian hipotesis menggunakan uji beda rata-rata atau uji-t dan diperoleh nilai sig (2-tailed) lebih kecil dari $\propto=0,05$ yakni 0,000 sehingga menyebabkan $\mathrm{H}_{0}$ ditolak dan $\mathrm{H}_{1}$ diterima yang berarti terdapat perbedaan hasil belajar siswa yang diajarkan dengan model pembelajaran kooperatif tipe number head together dan model pembelajaran konvensioanal pada materi peluang di kelas IX SMP Negeri 2 Taniwel, ini ditinjau dari hasil belajar siswa dalam bentuk uraian pada materi peluang.
\end{abstract}

Kata Kunci: Peluang, Number Head Together.

ABSTRACT. This study aims to determine the differences in student learning outcomes at SMP Negeri 2 Taniwel class IX on the opportunity material using conventional learning models and cooperative learning models number head together. The type of research used is experimental research (Experimental Research), with the research design Posttest Only Control Group Design. The population in this study were students of class IX SMP Negeri 2 Taniwel, JI. KH. Dewantara, East Taniwel sub-district, West Seram district, totaling 40 students. The sample in this study were students of class $\mathrm{IX}_{1}$ and class students IX 2 . The instrument used in this study was the final test instrument. The learning result test questions given consist of 5 questions in the form of descriptions. The data analysis technique in this study used descriptive statistical analysis and inferential statistical analysis (t-test) or the average difference test. The results of descriptive analysis showed that the average student learning outcomes in the experimental class were 74.71 and the average student learning outcomes in the control class were 56.91. While the prerequisite test results show that the data in the two normally distributed samples have a homogeneous variance, then hypothesis testing is carried out using the average difference test or t-test and the sig (2-tailed) value is smaller than $\propto=0.05$, namely 0.000 . thus causing $\mathrm{H}_{0}$ to be rejected and $\mathrm{H}_{1}$ to be accepted, which means that there are differences in student learning outcomes taught with the number head together cooperative learning model and conventional learning models on opportunity material in class IX SMP Negeri 2 Taniwel, this is in terms of student learning outcomes in the form of descriptions of the material opportunity.

Keyword: Opportunity, Number Head Together 


\section{PENDAHULUAN}

Belajar merupakan komponen ilmu pendidikan yang berkenan dengan acuan interaksi, baik bersifat eksplisit maupun tersembunyi Sagala Sagala(2014: 11). Hal yang sejalan juga dikatakan oleh Suryono dan Haryanto (2014: 9) bahwa belajar adalah suatu aktivitas atau proses untuk memperoleh pengetahuan, meningkatkan keterampilan, memperbaiki perilaku sikap dan mengkokohkan kepribadian. Berdasarkan pendapat para ahli diatas maka belajar merupakan interaksi antara siswa dengan guru yang dilakukan secara sadar, terencana baik didalam maupun diluar ruangan untuk meningkatkan kemampuan siswa.

Menurut Sudjana (2011:22) hasil belajar merupakan kemampuan-kemampuan yang dimiliki siswa setelah siswa tersebut menerima pengalaman belajarnya di dalam kelas. Sutikno (2014:180) mengatakan bahwa hasil belajar adalah kemampuan yang dimiliki siswa setelah mengalami aktivitas belajar. Dalam sistem pendidikan nasional rumusan tujuan pendidikan, baik tujuan kurikuler maupun tujuan instruksional, menggunakan klasifikasi hasil belajar dari Benyamin Blom yang secara garis besar membaginya menjadi tiga ranah, yakni ranah kognitif, ranah afektif, dan ranah psikomotor.

Marpaung (Ratumanan, 2015) berpendapat bahwa matematika tidak ada artinya kalau hanya dihafal. Pembelajaran yang didasarkan pada paradigma mengajar, siswa hanya mengandalkan telinga dan matanya dalam belajar, lalu berusaha menghafal apa yang mereka dengar dan lihat. Menurut Sanjaya (2008: 26) sering terjadi dalam kegiatan belajar mengajar, antara guru dan siswa tidak berhubungan. Guru asyik menjelaskan materi pelajaran di depan kelas, sementara itu siswa juga asyik dengan kegiatan sendiri. Siswa tidak peduli apa yang dikatakan guru karena faktor malas yang membuat siswa tidak fokus dalam kegiatan belajaran mengajar.
Model pembelajaran adalah suatu pola atau langkah-langkah tertentu yang diterapkan guru agar tujuan pembelajaran dapat dicapai dengan efektif. Sebagai salah satu komponen pembelajaran, pemilihan model pembelajaran akan sangat menunjang pencapaian tujuan pembelajaran. Pemilihan dan penggunaan model pembelajaran yang tepat oleh guru dapat membantu penyampaian materi pembelajaran secara maksimal kepada siswa. Penggunaan model pembelajaran yang tepat memungkinkan terjadinya kegiatan pembelajaran yang memberikan kesempatan kepada siswa untuk membangun sendiri pengetahuannya serta kegiatan pembelajaran yang mendorong siswa untuk bertanya dan berdiskusi yang berarti adanya interaksi timbal balik, baik antar sesama siswa maupun antar siswa dengan guru.

Rusman (2011: 209) mengatakan bahwa pembelajaran kooperatif merupakan suatu model pembelajaran dimana siswa dibagi dalam kelompok-kelompok kecil yang memiliki tingkat kemampuan yang berbeda-beda. Dalam menyelesaikan tugas kelompok, setiap anggota saling kerja sama dan membantu untuk memahami suatu bahan pembelajaran. Model pembelajaran kooperatif terbagi atas beberapa tipe salah satunya model pembelajaran kooperatif tipe Number Head Together (NHT). Menurut Trianto (2011: 82) model pembelajaran kooperatif tipe NHT adalah jenis pembelajaran kooperatif yang dirancang untuk mempengaruhi pola interaksi siswa sebagai alternatif terhadap struktur tradisional.

\section{METODE PENELITIAN}

Tipe penelitian yang digunakan adalah tipe penelitian eksperimental (Experimental Research) dengan desain penelitian Post-Test Only Control Group Design. Populasi dalam penelitian ini adalah seluruh siswa kelas IX SMP yang terdiri atas 2 (dua) kelas dengan jumlah total siswa adalah 40 siswa. Sampel yang digunakan adalah sampel populasi dengan nilai rata-rata kedua kelas tersebut relatif sama, yaitu rata-rata nilai 
siswa kelas IX1 sebesar 60,71 dan nilai rata-rata siswa kelas IX2 sebesar 60,52.

Selanjutnya ditentukan kelas eksperimen dan kelas kontrol. Kelas IX1 sebagai kelas eksperimen dan kelas IX2 sebagai kelas kontrol. Kelas eksperimen diberikan pembelajaran menggunakan pembelajaran kooperatif tipe Number Head Together, sedangkan kelas kontrol menggunakan model pembelajaran konvensional.

Dalam penelitian ini disusun Rencana Pelaksanaan Pembelajaran (RPP), Bahan Ajar (BA), dan Lembar Kerja Siswa (LKS) untuk kelas eksperimen disusun dan disesuaikan dengan model pembelajaran Number head togrther (NHT) sedangkan untuk kelas kontrol hanya dibuatkan Rencana Pelaksanaan Pembelajarn (RPP). Selain itu, disiapkan juga instrumen penelitian berupa soal tes berbentuk uraian.

Pelaksanaan pembelajaran pada masingmasing kelas, dilaksanakan mengacu pada RPP, BA, dan LKS yang telah disusun dan divalidasi oleh para pakar. Pada akhir kegiatan pembelajaran (setelah pertemuan keempat selesai) dilaksanakan tes untuk kedua kelas. Selanjutnya hasil tes dianalisis dengan menggunakan analisis statistik deskriptif dan statistik inferensial. Sebelum dilakukan uji-t maka perlu dilakukan uji prasyarat sampel dengan menggunakan uji normalitas dan uji homogenitas. Data diolah dengan menggunakan bantuan software SPSS versi 20.0

\section{HASIL PENELITIAN DAN PEMBAHASAN HASIL ANALISIS DESKRIPTIF}

Pelaksanaan kegiatan pembelajaran pada kelas eksperimen, yaitu kelas menggunakan pembelajaran kooperatif tipe Number Head Together dilakukan sebanyak 3 (tiga) pertemuan. Setiap tahapan pembelajaran dilaksanakan sesuai dengan RPP. Aktivitas pembelajaran didukung dengan BA dan LKS. Aktivitas siswa secara klasikal maupun kelompok membahas materi pada BA dan mengerjakan LKS, sedangkan aktivitas guru, yaitu berjalan berkeliling memperhatikan aktivitas setiap kelompok, dan memberikan bantuan penjelasan ketika kelompok mengalami kesulitan.

Pelaksanaan pembelajaran pada kelas kontrol, yaitu kelas yang menggunakan pendekatan konvensional, dilakukan juga sebanyak 3 (tiga) pertemuan. Pembelajaran berlangsung dengan menggunakan buku siswa serta menyelesaikan soal yang sudah disiapkan guru.

Pada akhir pembelajaran, dilakukan tes hasil belajar untuk kedua kelas tersebut. Tes dilakukan menggunakan instrumen yang sama untuk kedua kelas. Adapun hasil tes pada masingmasing kelas terdapat pada tabel 1 berikut

Tabel 3.1. Hasil belajar siswa

\begin{tabular}{|c|c|c|c|c|c|}
\hline \multirow{2}{*}{ Kualifikasi } & \multirow{2}{*}{ Nilai } & \multicolumn{2}{|c|}{ Kelas Eksperimen } & \multicolumn{2}{c|}{ Kelas Kontrol } \\
\cline { 3 - 6 } & & $\mathrm{f}$ & $\%$ & $\mathrm{f}$ & $\%$ \\
\hline Sangat Baik & $\mathrm{x} \leq 90$ & 0 & $0 \%$ & 0 & $0 \%$ \\
\hline Baik & $75 \leq \mathrm{x}<90$ & 2 & $10 \%$ & 0 & $0 \%$ \\
\hline Cukup & $60 \leq \mathrm{x}<75$ & 16 & $80 \%$ & 7 & $35 \%$ \\
\hline Kurang & $40 \leq \mathrm{x}<60$ & 2 & $10 \%$ & 11 & $55 \%$ \\
\hline Sangat Kurang & $\mathrm{x}<40$ & 0 & $0 \%$ & 2 & $10 \%$ \\
\hline
\end{tabular}


Dari data pada tabel 3.1 di atas, terlihat bahwa pada kelas eksperimen tidak ada siswa yang memiliki kualifikasi sangat baik, 2 siswa (10\%) memiliki kualifikasi baik. Pada kelas kontrol tidak ada siswa yang memiliki kualifikasi sangat baik dan baik. Pada kelas eksperimen, kualifikasi cukup terdapat 16 siswa $(80 \%)$ serta kualifikasi kurang berjumlah 2 siswa $(10 \%)$. Pada kelas kontrol, kualifikasi cukup 7 siswa (35\%) dan untuk kualifikasi kurang dan sangat kurang berturut- turut adalah 11 siswa (55\%) dan 2 siswa (10 $\%)$. Dari perhitungan nilai rata-rata hasil belajar siswa pada kelas eksperimen dan kelas kontrol diperoleh hasil sebagaimana disajikan pada Tabel 2 berikut.

Tabel 3.2. Rata-rata hasil belajar siswa

\begin{tabular}{|l|l|}
\hline Kelas & Rata-rata \\
\hline Ekseperimen & 74,71 \\
\hline Kontrol & 56,91 \\
\hline
\end{tabular}

Data pada tabel 3.2, nampak bahwa nilai ratarata siswa pada kelas eksperimen lebih tinggi, jika dibandingkan dengan nilai rata-rata siswa pada kelas kontrol. Selisih nilai rata-rata kedua kelas sebesar 17,8 .

\section{HASIL UJI HIPOTESIS}

Sebelum dilakukan uji hipotesis komparatif, perlu dilakukan terlebih dahulu analisis prasyarat. Analisis prasyarat yang dimaksudkan adalah uji normalitas dan uji homogenits varians. Untuk menguji normalitas data hasil belajar digunakan rumus Chi Square. Uji normalitas data dilakukan menggunakan aplikasi SPSS 20.0. Hasil uji normalitas hasil belajar pada kedua kelas disajikan pada Tabel 3.3 berikut.

Tabel 3.3. Uji Normalitas $(a=0,05)$

\begin{tabular}{cccc}
\hline Kelas & Sig & a & Kesimpulan \\
\hline Eksperimen & 0,86 & 0,05 & Terima $_{0}$ \\
Kontrol & 0,062 & 0,05 & Terima Ho $_{0}$ \\
\hline
\end{tabular}

Data pada tabel 3 menunjukkan bahwa pada kelas eksperimen diperoleh nilai sig lebih besar dari nilai $a=0,05$, yaitu sebesar 0,86 . Hal ini serupa juga pada kelas kontrol diperoleh nilai
Sig lebih besar dari nilai $a=0,05$, yaitu sebesar 0,062 . Ini berarti bahwa $\mathrm{H}_{1}$ ditolak dan $\mathrm{Ho}_{0}$ diterima. Dengan demikian dapat disimpulkan bahwa data penelitian berdistribusi normal.

Setelah diketahui data berdistribusi normal, selanjutnya dilakukan uji homogenitas. Uji homogentitas menggunakan uji-F untuk membandingkan varians kedua kelas. Hasil pengujian homogenitas ditunjukkan pada tabel 3.4 berikut ini.

Tabel 3.4. Uji Hoimogentas $(a=0,05)$

\begin{tabular}{cccc}
\hline Kelas & Sig & a & Kesimpulan \\
\hline $\begin{array}{c}\text { Eksperimen } \\
\text { dan Kontrol }\end{array}$ & 0,198 & 0,05 & ${\text { Terima } \mathrm{H}_{0}}$
\end{tabular}

Data pada tabel 4 menunjukkan bahwa nilai Sig lebih besar dari nilai $a=0,05$, yaitu 0,198 . Ini berarti bahwa $\mathrm{H}_{1}$ ditolak dan $\mathrm{H}_{0}$ diterima, sehingga dapat dikatakan bahwa data hasil belajar siswa kedua kelas homogenitas.

Berdasarkan data hasil uji normalitas dan homogenitas yang menunjukkan bahwa data berdistribusi normal dan homogen, maka dapat dilanjutkan dengan uji $t$ untuk mengetahui perbedaannya. Hasil uji t terdapat pada tabel 5 berikut ini.

Tabel 3.5. Hasil Uji Hipotesis Menggunakan Uji t $(a=0,5)$

\begin{tabular}{cccc}
\hline $\begin{array}{c}\text { Hasil } \\
\text { belajar }\end{array}$ & Sig & a & Kesimpulan \\
\hline Tes akhir & 0,00 & 0,05 & Terima H $_{1}$ \\
\hline
\end{tabular}

Dari data pada tabel 3.5 menunjukkan bahwa nilai Sig (2-tailed) lebih kecil dari nilai $\mathrm{a}=$ 0,05 , yaitu 0,00 . Ini berarti pada taraf signifikan a $=0,05 \mathrm{H}_{0}$ ditolak dan $\mathrm{H} 1$ diterima. Dengan demikian dapat disimpulkan bahwa ada perbedaan hasil belajar siswa kelas IX SMP Negeri 2 Taniwel yang diajarkan dengan menggunakan model pembelajaran kooperatif Number Head Together dan model pembelajaran 
konvensional pada materi peluang di kelas IX SMP Negeri 2 Taniwel

\section{PEMBAHASAN}

Penelitian eksperimen mengenai perbedaan hasil belajar siswa yang diajarkan dengan model pembelajaran kooperatif tipe number head together dan model pembelajaran konvensional pada materi peluang di kelas IX SMP Negeri 2 Taniwel ini ditinjau dari penilaian tes hasil belajar siswa dalam bentuk uraian pada materi peluang.

Penelitian yang dilakukan di SMP Negeri 2 Taniwel ini melibatkan dua kelas yang dijadikan kelas control dan kelas eksperimen. Untuk kelas control merupakan kelas [IX】_2 yang diajarkan dengan model pembelajaran konvensional, sedangkan untuk kelas eksperimen pada penelitian ini adalah kelas [IX _ 1 yang diajarkan dengan model pembelajaran kooeratif tipe number head together. Setelah diberikan perlakuan seperti yang dijelaskan pada deskripsi awal diatas, kemudian diberikan tes akhir untuk mengetahui bagaimana hasil belajar kedua kelas setelah diberikan perlakuan yang berbeda.

Berdasarkan hasil penelitian yang dilakukan pada kelas control dan kelas eksperimen diperoleh nilai rata-rata untuk kelas eksperimen 74,71 lebih besar dari kelas control yaitu 56,91. Hal ini menunjukan bahwa hasil belajar siswa pada kelas eksperimen lebih baik dari pada hasil belajar kelas control.

Pada hasil uji hipotesis yang digunakan dengan uji-t diperoleh Sig. (2-tailed) lebih kecil dari $a=0,05$ yakni 0,000 yang berarti terdapat perbedaan hasil belajar siswa yang diajarkan dengan model pembelajaran kooperatif tipe number head together dan model pembelajaran konvensional pada materi peluang di kelas IX SMP Negeri 2 Taniwel ini ditinjau dari penilaian tes hasil belajar siswa dalam bentuk uraian pada materi peluang.
Berdasarkan hasil penelitian diatas menunjukan bahwa model pembelajaran kooperatif tipe NHT lebih baik dari pada model pembelajaran konvensioal khususnya pada materi peluang, karena telah terbukti dapat meningkatkan hasil belajar siswa. Hal ini ini disebabkan model pembelajaran kooperatif lebih menarik perhatian siswa, karena pembelajarannya tidak monoton dan tidak membosankan melainkan membuat siswa aktif, melatih siswa untuk bias bekerja sama dalam membangun pemahaman. Hal ini sesuai yang dikatakan Krismanto (2003:63) tentang kelebihan model pembelajaran kooperatif yani: melatih siswa untuk dapat bekerja sama dan dapat menghargai pendapat orang lain, melatih siswa untuk bisa menjadi tutor sebaya, memupuk rasa kebersamaan, membuat siswa menjadi terbiasa dengan perbedaan. Sedangkan model pembelajaran konvensional bukan tidak efektif hanya saja karena pembelajarannya terlalu monoton membuat siswa menjadi bosan dan tidak dapat membangun pemahaman mereka.

Dari analisis hipotesis menggunakan uji $\mathrm{t}(\mathrm{t}-$ test) diperoleh bahwa sig(2-tailed) 0,00<a=0,05, yang berarti bahwa perbedaan hasil belajar berkaitan dengan penggunaan kedua model pembelajaran adalah signifikan. Dengan kata lain, hasil belajar materi peluang yang diperoleh melalui pembelajaran kooperatif tipe Number Head Together secara signifikan lebih meningkat bila dibandingkan dengan pendekatan konvensional. Hal ini disebabkan karena model pembelajaran kooperatif lebih menarik perhatian siswa, karena pembelajarannya tidak monoton dan tidak membosankan melainkan membuat siswa akyif, melatih siswa untuk bisa bekerjasama dalam membangun pemahaman. Hal ini sesuai dengan yang dikatakan Krismanto (2003: 63) tentang kelebihan model pembelajaran kooperatif yakni: melatih siswa untuk dapat bekerjasama dan dapat menghargai pendapat orang lain melatih siswa untuk menjadi tutor sebaya, memupuk rasa kebersamaan, siswa menjadi terbiasa dengan perbedaan. Sedangkan model pembelajaran 
konvensional bukan tidak efektif hanya saja karena pembelajarannya terlalu monoton membuat siswa menjadi bosan dan tidak dapat membangun pemahaman mereka

\section{SIMPULAN}

Berdasarkan hasil penelitian maka dapat disimpulkan bahwa terdapat perbedaan hasil belajar antara siswa yang diajarkan dengan model pembelajaran kooperatif tipe Number Head Together dan model pembelajaran konvensional. Pada kelas eksperimen tidak ada siswa yang memperoleh nilai sangat rendah sedangkan pada masih ada dua siswa yang memperoleh nilai sangat rendah. $65 \%$ siswa pada kelas kontrol berada pada kategori di bawah cukup. Hal ini menunjukkan bahwa kelas eksperimen yaitu kelas yang diajarkan dengan model pembelajaran kooperatif tipe Number Head Together memberikan hasil belajar yang lebih baik dibandingkan dengan model pembelajaran konvensional.

\section{DAFTAR PUSTAKA}

Arikunto, S.2013. Prosedur Penilittian. Jakarta: Rineka Cipta

Budiningsih A. 2013. Belajar dan Pembelajaran. Jakarta: Rineka Cipta

Krismanto. 2003. Beberapa Teknik, model dan Strategi dalam Pembelajaran Matematika. PPPG Matematika Yogyakarta

Patty. A. E. 2014. Perbedaan Hasil Belajar Siswa Kelas VII SMP Kristen I Leihitu Barat Yang
Diajarkan Dengan Model Pembelajaran Kuantum Dan Model Model Pembelajaran Konvensional Pada Materi PLSV. FKIP Universitas Pattimura

Purwanto, N. 2009. Evaluasi Hasil Belajar. Yogyakarta: Pustaka Belajar.

Ratumanan, T. G. 2002. Belajar dan Pembelajaran. Surabaya: Unesa University Press.

Ratumanan, T. G. 2015. Inovasi Pembelajaran. Surabaya: Unesa University Press.

Rusman. 2011. Model-Model Pembelajaran Mengembangkan Profesionalisme Guru. Jakarta: Rajawali Press.

Shoimin, A. 2016. Model Pembelajaran Inovatif dalam Kurikulum 2013. Yogyakarta: Ar-Ruzz Media.

Sagala, S. 2014. Konsep dan Makna Pembelajaran untuk Membantu Memecahkan Problematika Belajar san Mangajar. Bandung: Alfabeta.

Slamento. 2010. Belajar dan Faktor-Faktor yang Mempengaruhinya. Jakarta: Rineka Cipta

Sutikno \& Solori. 2014. Metode dan Model-Model Pembelajaran. Holistitica. Lombok.

Trianto. 2011. Mendesain Model Pembelajaran Inovatif Progresif. Edisi Ke-4. Jakarta: Kencana. 